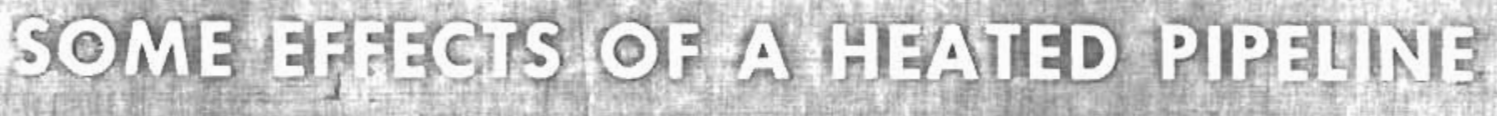

ON GROUND WATER HLOW IN ALASKA

By Charlos E. Slow ond Dohn D. Bredehoof?

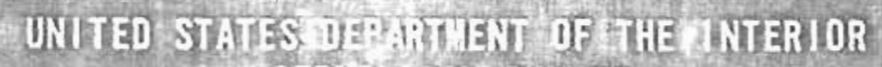

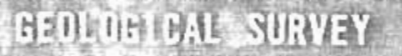

Water Resournes in: sion = Alaska District

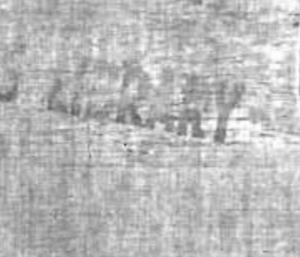




\author{
UNITED STATES \\ DEPARTMENT OF THE INTERIOR \\ GEOLOGICAL SURVEY
}

\title{
SOME EFFECTS OF A HEATED PIPELINE ON GROUND-WATER FLOW IN ALASKA
}

\section{By}

Charles E. Sloan and John D. Bredehoeft

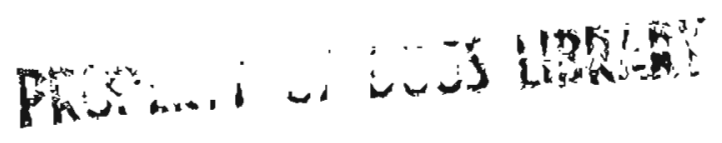

\author{
Open-File Report \\ July 1972
}


CONTENTS

Page

Abstract. . . . . . . . . . . . . . . . . . 4

Introduction. . . . . . . . . . . . . . . . . . 5

Artesian conditions beneath permafrost. . . . . . . 7

Model studies - seasonally frozen conditions..... 9

Mathematical model.................. 19

Cryostatic pressures developed in a shallow talk. . . 21

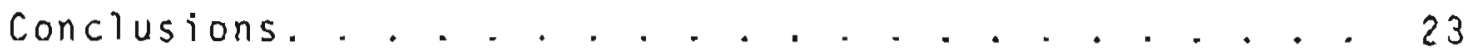

Quick conditions. . . . . . . . . . . . . . 23

Icings. . . . . . . . . . . . . . . . . 23

Icing mounds. . . . . . . . . . . . . . . 24

References... . . . . . . . . . . . . . . . 25 
I LLUSTRATIONS

Page

Figure 1. Schematic plan view of the situation modeled.......................... 14

2. Mead distribution summer and winter. . . 16

3A. Geologic section A-A'.......... . 16

3B-3F. Geologic section showing:

3B. Head distribution in the summer. . . 16

3C. Head distribution in the winter

without the pipeline....... . 17

3D. Head distribution in the winter in the vicinity of the pipeline... . . 17

3E. Head distribution in the winter with

an impermeable barrier downstream. . 18

3F. Head distribution in the winter with

the backfilled trench closer to the

change in permeability...... . 18

4A. Geologic section A-A'.......... 20

$4 B-4 C$. Geologic section showing:

$4 B$. Winter head distribution with back-

filled pipeline trench..... . 20

4C. Winter head distribution with a larger

contrast in permeability between

layers... . . . . . . . . 20

TABLES

Table 1. Selected table of flowing wells in the

Fairbanks area, from cederstrom (1963). . 8

2. Hydraulic conductivity of various soils,

from Casagrande and Fadum (1940).... . 12

3. Selected stream gradients along the pipeline

route............... 13 


\section{SOME EFFECTS OF A HEATED PIPELINE ON}

GROUND-WATER FLOW IN ALASKA

By Charles E. Sloan and John D. Bredehoeft

\section{ABSTRACT}

The thaw bulb produced by a heated pipeline buried in a stream channel may intercept water confined in shallow unfrozen zones beneath a seasonally frozen layer. Resulting movement of ground water through the thaw bulb might produce quick conditions in the pipeline foundation materials. A digital model showed that such conditions are not likely to occur. Test driling along the proposed route of the pipeine confirms this conclusion. An exception may be the situation in which the pipeline is buried in fine sand overlying a highly permeable coarse sand or grave?.

The results of model studies demonstrate that the heated trench will focus ground-water discharge near the pipeline, especially in winter. Such discharge will increase the number and size of icings.

Explosive icing mounds apparently result from high crystalization pressures that develop within a closed talik. The thaw bulb close to the buried pipeline relieves the pressure that leads to such conditions.

Potential problems related to thaw-bulb enlargement by heat convection and thaw-instability of fine-grained materials are not treated in this analysis. 
According to the present plans, the proposed transAlaska pipeline from erudhoe Bay to Valdez, Alaska, will be buried for more than half of its 789-mile length. The buried pipeline will in places influence ground-water flow patterns.

The pipeline is aligned with major streams through the mountainous segments of the route because their valleys provide natural routes of low relief. Such routing also tends to avoid sidehill construction and takes advantage of well-drained or unfrozen foundation materials. Within these segments the pipe?ine will cross many tributary and mainstem streams and will be buried in the associated channel, flood plain, terrace, and alluvial fan deposits.

The principal aquifers within the pipeline corridor are the alluvial deposits associated with the streams. Thus, most of the interactions of the buried pipeline with groundwater flow systems will occur in the stream valleys. Unfrozen alluvial deposits consisting largely of permeable sand and gravel in the channels, flood plains, terraces, and aljuvial fans of the river valleys are the principal aquifers along the pipeline route. The extent and thickness of permafrost limits the occurrence of ground water. As the volume of frozen ground decreases southward along the route consistent with the regional zonation of permafrost, the amount of ground water increases. In the Arctic and sub-Arctic regions substantial areas of unfrozen alluvium are generally found only beneath or beside the streams and lakes that do not completely freeze in the winter. Shallow ground water is unconfined during the summer but usualiy is canfined by seasonal frost during the winter, with consequent buildup of artesian head. In some areas along the pipeline route, particularly in the Fairbanks area, ground water is confined by permafrost in deeper artesian systems. 
Stipulations to be made part of any permit issued by the Department of the Interior in connection with the proposed trans-Alaska pipeline have been prepared by the Department of the Interior (1972) and the Federal Task Force on Alaskan 0 il Development. The technical stipulations al low conventional burial in thaw-stable sand and gravel, competent bedrock, or soil naturally devoid of permafrost. Many of the hydrologic problems associated with thaw of permafrost in fine-grajned materials as discussed by Lachenbruch (1970) can be avoided through adherence to the stipulations; these problems will not be discussed further in this report.

The thaw bulb produced by the heated pipeline may intercept zones of confined water beneath permafrost or in shallow unfrozen zones beneath a seasonally frozen layer. Consequent ground-water discharge through the thaw bulb may have sufficient velocity to cause quick conditions in the pipeline foundation materials. This report examines and discusses some of the effects that a heated pipeline can have on artesian systems that occur along the pipeline and evaluates by means of a digital model the likelihood of occurrence of quick conditions. The pipeline's effect on the occurrence of icings and icing mounds is also discussed.

Transfer of heat by convection of ground water in the thaw bulb can occur in coarse-grained materials and will result in enlargement of the thaw bulb in an irregular fashion at a much faster rate than that resulting from simple conduction of heat. Although thaw-bulb enlargement by heat convection can be a problem, it is not within the scope of this study. Another limitation of the study is that the simple boundary conditions assumed for the model do not represent the complex boundaries that exist in nature. However, they do represent reasonable estimates of boundary values based on field conditions. 


\section{ARTESIAN CONDITIONS BENEATH PERMAFROST}

Information on ground water in Alaska is very scant. cederstrom (1963, p. 27-30) described artesian conditions that exist in the Fairbanks area, which will be crossed by the pipeline; here, perennially frozen silt in the valleys and on the lower hillslopes is the confining layer over unfrozen gravels or fractured and beathered bedrock. This condition is probably typical of many of the valleys crossed by the pipeline route in the Yukon-Tanana upland. Table 1 is taken from cederstrom's report (1963) to show flowing artesian wells and their depths. The well numbers are identification numbers for location on cederstrom's map.

As can be seen from table 1 , depths of flowing wells range from 80 to 280 feet with a mean depth of 155 feet. Lachenbruch's calculations (1970, p. 5) indicate that if the pipeline were buried in fine-grained permafrost sediments, the thaw bulb would reach approximately 50 feet in depth in 20 years. However, the thaw bulb could become much larger if heat transfer occurred by convection of flowing water in the thaw bulb. Because the technical stipulations do not allow conventional burial in fine-grained, ice-rich permafrost sediments, interception of confined zones under high artesian pressure by the thaw bulb does not seem to be very likely.

Logs of test borings made for the Alyeska Pipeline Service company and geologists' fielo notes were examined for some 1,700 sites along the pipeline route to see where and under what kind of head conditions ground water was found. Artesian heads above the land surface were found in only two test holes. Test hole $1-41$ on the Sagavanirktok River near Franklin Bluffs was 6 feet deep and had a water level 0.5 foot above the land surface. Test hole 16-78 near Lost creek in the Yukon-Tanana upland was 51 feet deep and had a water level 1.0 foot above the land surface. 
Table 1.--Selected table of flowing wells in the Fairbonks area, from Cederstrom (1963).

\begin{tabular}{|c|c|c|c|}
\hline We]l no. & Location & Nater level & Depth \\
\hline $363 a$ & Off Farmers Loop & $+1 /$ & 132 \\
\hline$b$ & Off Farmers Loop & + & 127 \\
\hline$c$ & Off Farmers Loop & + & 160 \\
\hline 368 & Off McGrath Road & + & 280 \\
\hline 370 & Off Mcrsrath Road & +8 & 124 \\
\hline 373 & Steese Highway & +7 & 103 \\
\hline 385 & Steele Creek Road & + & 80 \\
\hline 386 & Chena Hot Springs Road & +5 & 149 \\
\hline 388 & Off Chena Hot Spr. Road & + & 205 \\
\hline 396 & Farmers Loop Road & +10 & 126 \\
\hline 397 & Farmers Loop Road & + & 268 \\
\hline 398 & Farmers Loop Road & +10 & 108 \\
\hline
\end{tabular}

$1 /$ + indicates static water level above land surface 
Water was found in test hole 16-78 at a depth of 9.5 feet while drilling.

Other test holes showed a substantial rise in water level above that found during driliing, but water did not reach the land surface. For instance, water found at 19 feet while drilling test hole 7-4l (35 feet deep) on the flood plain of the Little Salcha giver rose to a level of 4 feet below the land surface after boring. Most of this test drilling was done under winter conditions from September through November and Feoruary through May.

\section{MODEL STUDIES - SEASONALLY FROZEN CONDITIONS}

Even in highly permeable materials, a heated, buried pipeline will change the pattern nf ground-water flow. During the winter the pipeline will be the focus of groundwater discharge. It is conceivable that this discharge could cause problems of material stability, including quick conditions.

Idealized models of typical ground-water situations were analyzed to investigate changes in flow produced by a buried pipeline in an area of seasonally frozen ground. Both (1) the likelihood of developing quick conditions and (2) the change in focus of ground-water discharge were examined. The situations selected are believed to be reasonably typical of conditions in stream valleys or on alluvial fans in the Alaska Range or the Brooks Range. Throughout the model studies we have assumed the pipe trench to be backfilled with material of the same permeability as that adjacent to the trench. 
Quick conditions, as the texts in soil mechanics point out, occur if the hydraulic gradient approaches a critical value of approximately 1, or

$$
\frac{\partial h}{\partial s}=1 \text { (i.e. } 1 \text { foot per foot) }
$$

where $h$ is the hydraulic head and $s$ is distance. The model studies were designed to test whether and under what conditions such high head gradients could occur.

Scott (1963, p. 96) points out that the seepage force on the soil is given by

$$
J=\frac{a h}{\partial S} \mathrm{~T}
$$

where $J$ is the seepage force per unit volume, $\frac{\partial h}{\partial s}$ is the hydraulic gradient, and $y_{w}$ is the unit weight of water.

Scott states $(p \cdot 96)$ :

"For the particular case in which the tube (soil column).... is vertical, the forces acting on a unit of soil volume are its buoyant unit weight and the seepage force. If the head is increased to the point at which these forces become equal, the soil will just be at the point of being carried upward in the tube, and there will be effectively no grain-to-grain pressure. The gradient at which this occurs can be computed from the balance of forces."

Thus:

$$
\frac{\partial h}{\partial s} r_{W}=r_{b}
$$

where $r_{b}$ is the buoyant unit weight.

Since $y_{W}$ is approximately equal to $y_{b}$, the critical gradient is approximately

$$
\frac{\partial h_{1}}{\partial s}=\frac{Y_{D}}{\gamma_{W}}=1
$$




\section{Scott goes on:}

"Because there is no intergranular pressure, the soil will exhibit no shearing strength and will have the properties of a fluid. A body placed in a qujck soil would then float at a level appropriate to its density and that of the quick soil mass.

It is of interest to note that the critical gradient depends only on the specific gravity of the soil grains and the void ratio of the soil, and the equation does not say anything about the grain size of the soil. Therefore, the reaction occurs independently of the grain size.

In soils consisting of larger grain sizes, such as gravel, the quantity of water that would be required to maintain a critical gradient through the soil would be very large, and in practice it would be extremely unlikely to encounter volumes of water sufficient to maintain gravel in a quick condition."

The values of hydraulic conductivity (K) assigned to the mode 3 were based on average values of $k$ for different alluvial materials. Table 2 is taken from Casagrande and Fadum (1940).

Stream gradients were measured on the topographic map of the pipeline route (contour interva) $=10$ feet) for a number of streams. Table 3 shows these gradients, which range from about 2 feet per mile on Gunn Creek $F$ lat near Summit Lake to almost 300 feet per mile on the alluvial fan of Flood Creek, a tributary of the Delta River. From the stream gradients in table 3 , a hydraulic gradient on the water-table surface (summer condition) of about 100 feet per mile was assumed as being a reasonable upper limit.

In the first series of results, we examine the simple situation of an aquifer with a reasonably uniform permeability and no change in aquifer thickness in the upstream or downstream direction (fig. 1). The results for a representative geologic section of the situation are depicted in figure 2. A general head drop of 10 feet over the 480 foot length of modeled reach was imposed. Constant 


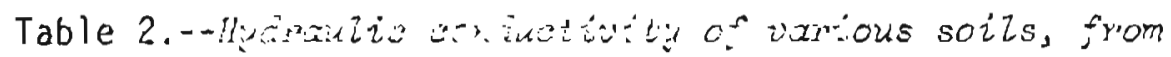
Casagranke anci Fadum (1940).

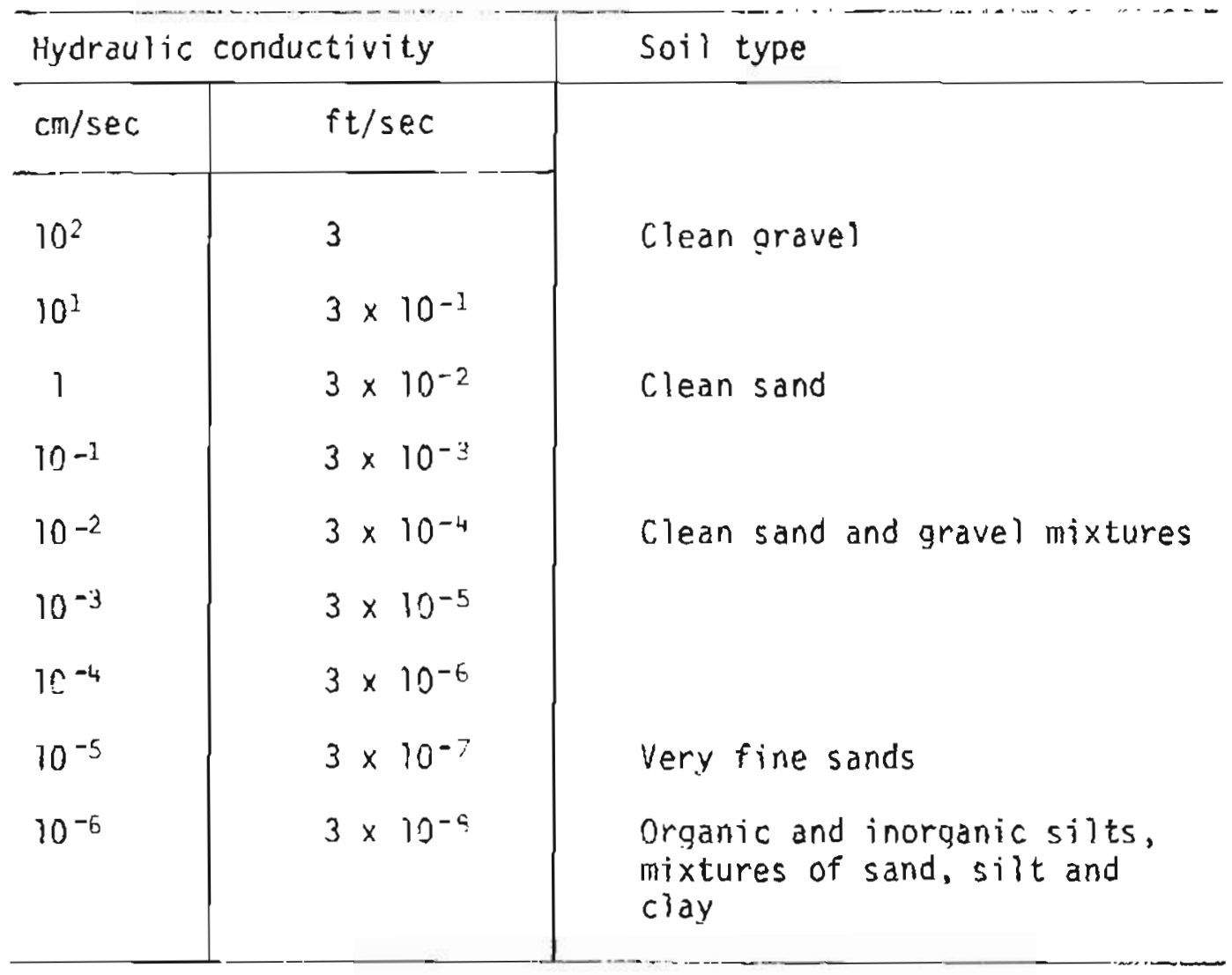

12 


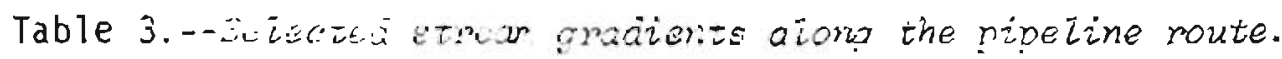

\begin{tabular}{|c|c|c|}
\hline Streams & Percent & $\mathrm{ft} / \mathrm{mi}] \mathrm{e}$ \\
\hline \multicolumn{3}{|l|}{ Sag River } \\
\hline $\begin{array}{l}\text { Upper reach } \\
\text { Middle reach } \\
\text { Near Ivishak River } \\
\text { Lower reach }\end{array}$ & $\begin{array}{r}00.42 \\
0.33 \\
0.25 \\
0.74\end{array}$ & $\begin{array}{l}22 \\
17.5 \\
73 \\
7.5\end{array}$ \\
\hline \multicolumn{3}{|l|}{ Dietrich River } \\
\hline $\begin{array}{l}\text { Above Big Jim Creek } \\
\text { Above Bettles River }\end{array}$ & $\begin{array}{l}0.50 \\
0.33\end{array}$ & $\begin{array}{l}26.5 \\
17.5\end{array}$ \\
\hline \multicolumn{3}{|l|}{ Middle Fork Koyukuk River } \\
\hline $\begin{array}{l}\text { Above Hammond River } \\
\text { Below Porcupine Creek }\end{array}$ & $\begin{array}{l}0.25 \\
0.17\end{array}$ & $\begin{array}{r}13 \\
9\end{array}$ \\
\hline \multicolumn{3}{|l|}{ Delta River } \\
\hline $\begin{array}{l}\text { 8elow Black Rapids } \\
\text { Below Phelan Creek confluence }\end{array}$ & $\begin{array}{l}0.71 \\
0.50\end{array}$ & $\begin{array}{l}38 \\
26\end{array}$ \\
\hline \multicolumn{3}{|l|}{ Alluvial Fans } \\
\hline $\begin{array}{l}\text { Flood Creek } \\
\text { Trims Creek }\end{array}$ & $\begin{array}{l}5.55 \\
4.17\end{array}$ & $\begin{array}{l}294 \\
208\end{array}$ \\
\hline \multicolumn{3}{|l|}{ Phelan Creek } \\
\hline $\begin{array}{l}\text { At lower crossing } \\
\text { Below McCallum Creek } \\
\text { Above highway bridge }\end{array}$ & $\begin{array}{l}1.17 \\
1.03 \\
1.60\end{array}$ & $\begin{array}{l}62 \\
54 \\
84\end{array}$ \\
\hline \multicolumn{3}{|l|}{ Gunn Creek } \\
\hline Flat & 0.04 & 2 \\
\hline \multicolumn{3}{|l|}{ Tsina River } \\
\hline In upper reach & 1.00 & 53 \\
\hline Lowe River & & \\
\hline Below Sheep Creek & 0.88 & 46 \\
\hline Sheep Creek & & \\
\hline Fan & 3.00 & 150 \\
\hline
\end{tabular}




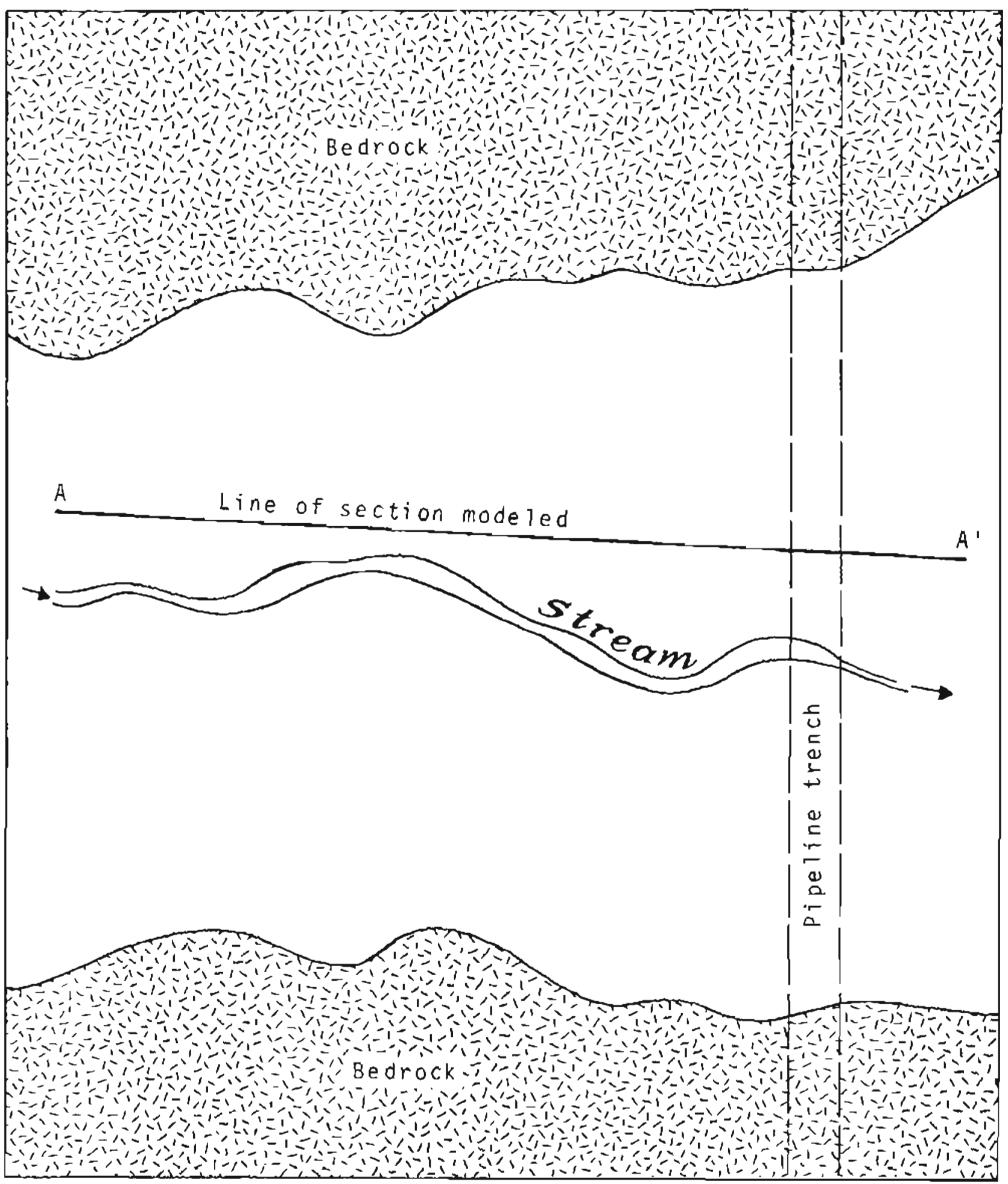

Figure 1.--Schematic plan view of the situation modeled. 
head boundaries, arbitrarily chosen as zero and ten, at each end of the modeled section assure this drop. Although the system is artesian, the heads are approximately the same in the winter as in the summer.

There will be no seasonal freezing of material over a heated pipeline. This unfrozen zone will be one of relief of artesian pressure, a place for potential ground-water discharge. Under the conditions assumed for figure 2, a uniform change in permeability does not change the head distribution, although it will change the quantity of flow.

The situation is considerably different if a zone of lower permeability is present in the aquifer (fig. 3A). figures $3 \dot{A}-3 F$ show a series of results for geologic conditions in which a more permeable zone becomes less permeable downgradient.

The zone of low permeability creates an area of groundwater discharge in the summer (fig. 3B). A seasonally frozen layer, which effectively confines the aquifer in the winter, can produce artesian heads in this area (fig. 3C). Burying a heated pipeline within the zone of lower permeability near the area of the permeability change strongly focuses the discharge at the pipeline (fig. 3D). Head drops of approximately 1 in 5 occur--still below the critical values for quick conditions. The conditions are somewhat worse if a bedrock barrier exists farther downstream. This, of course, focuses all the discharge at the pipeline (fig. 3E). If the pipeline is buried close to a zone of permeability change, higher head gradients can exist (fig. $3 F)$; but it is doubtful if critical gradients will be produced. 


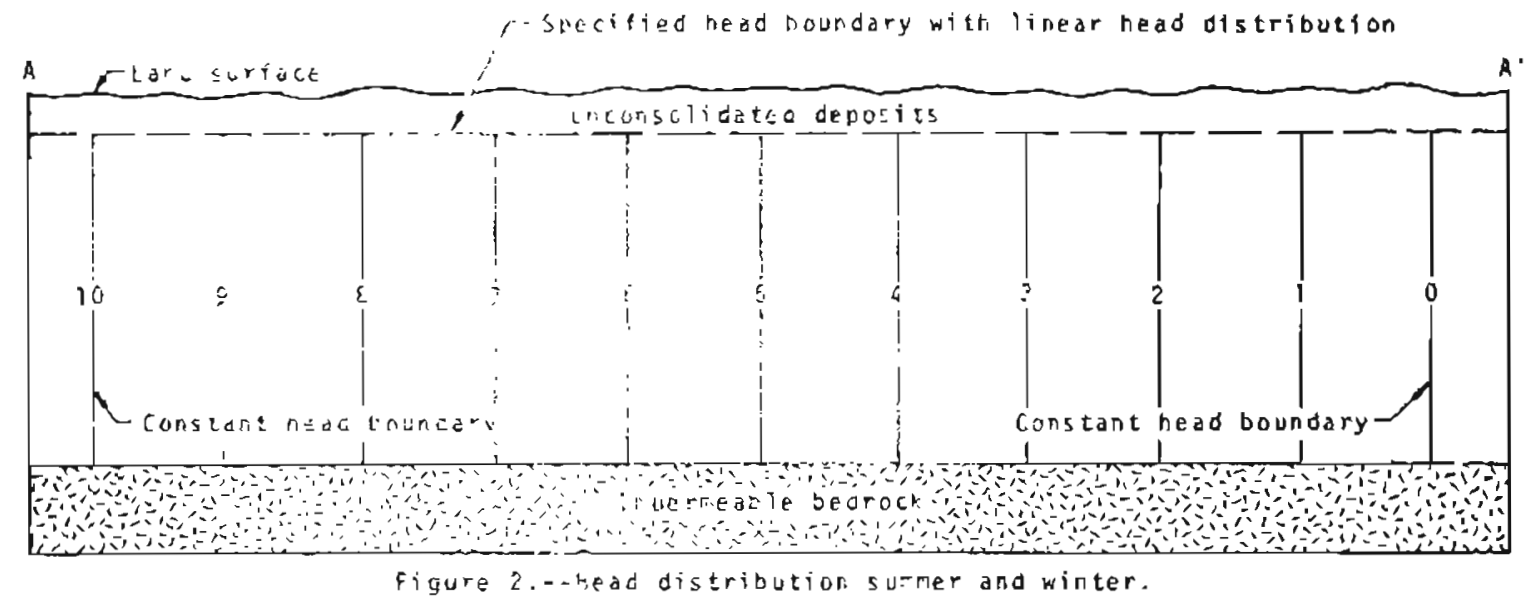

figure 2.-.head distribution surmer and winter.

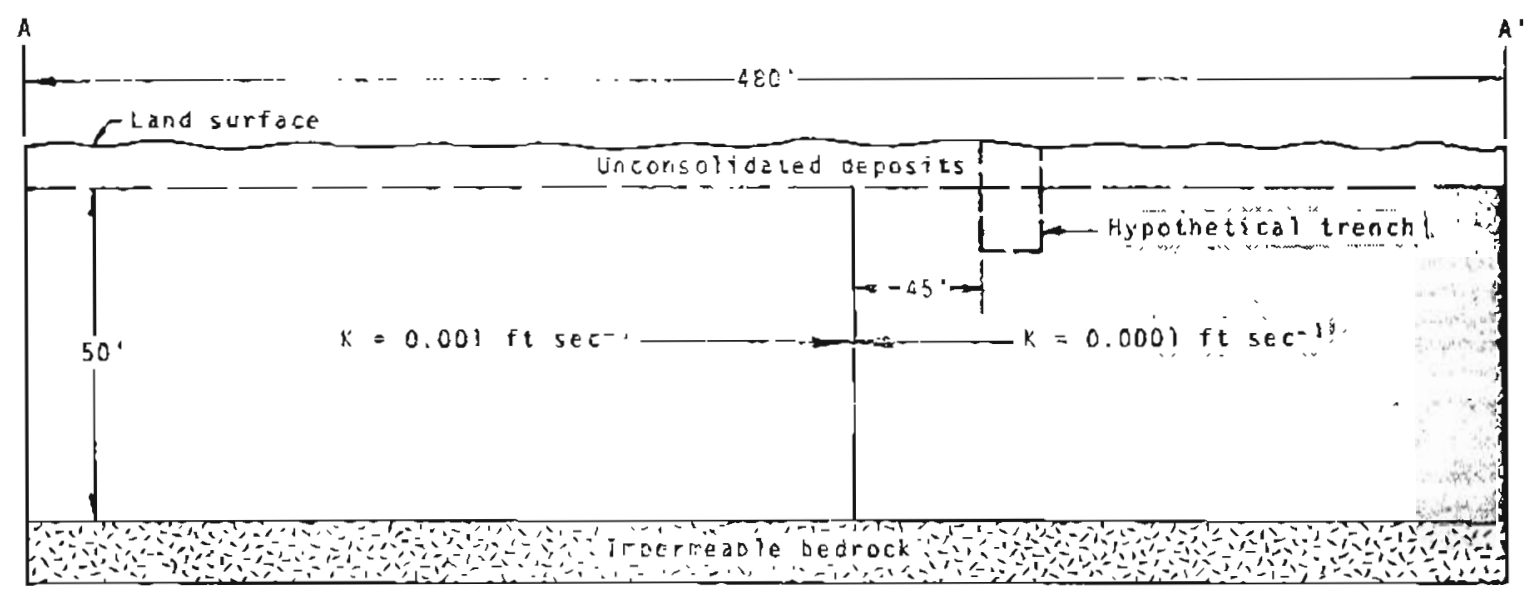

Figure 3h.--jeologic section A-A'.

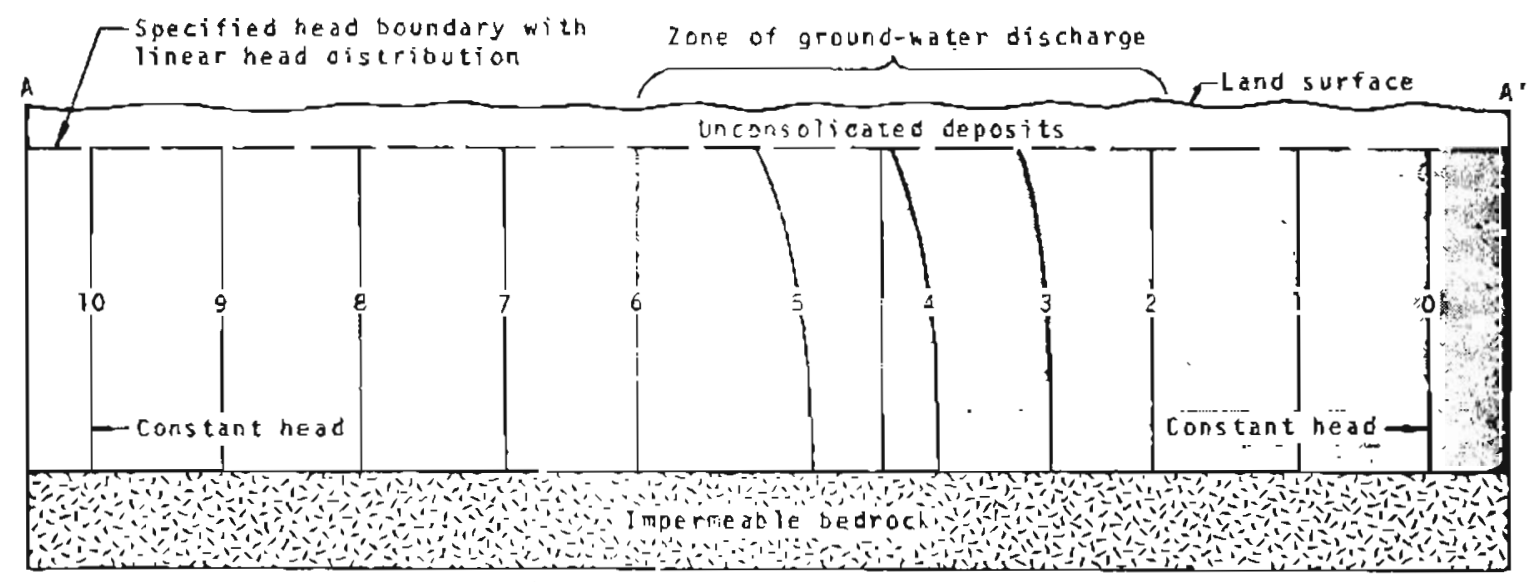

Figure $3 E$. - liead distribution in the summer. 


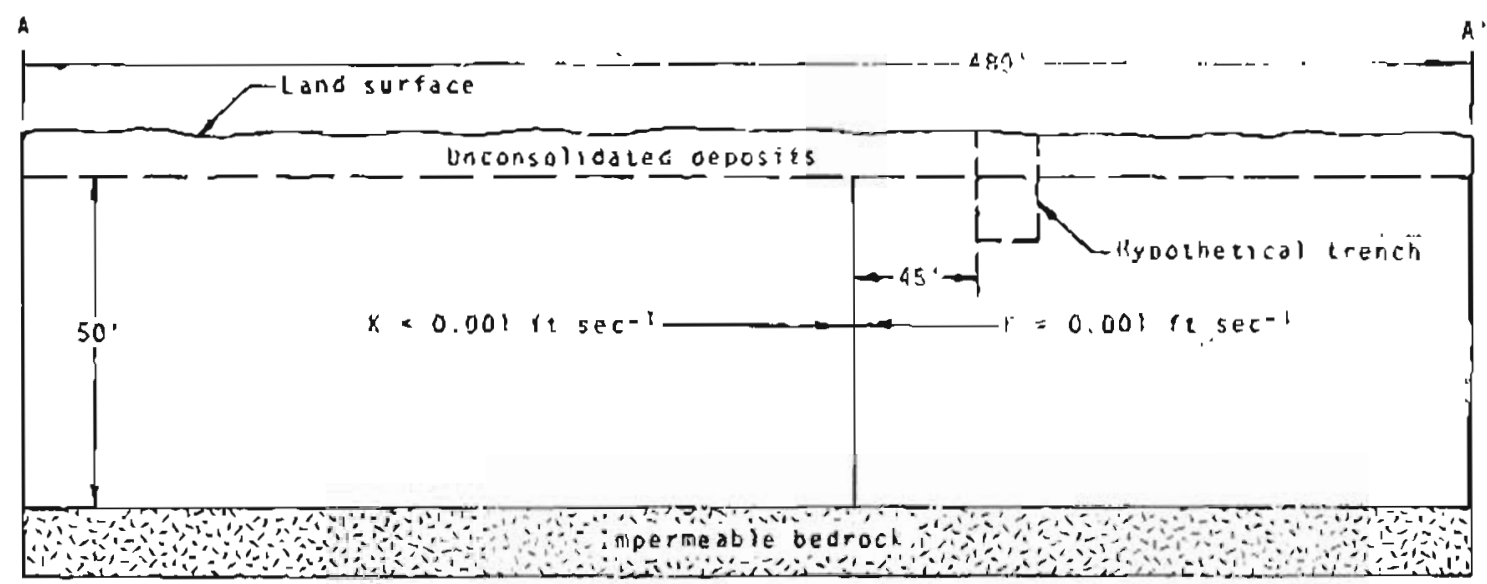

Fiqure 3A.--Geologic secetón $A-A$.

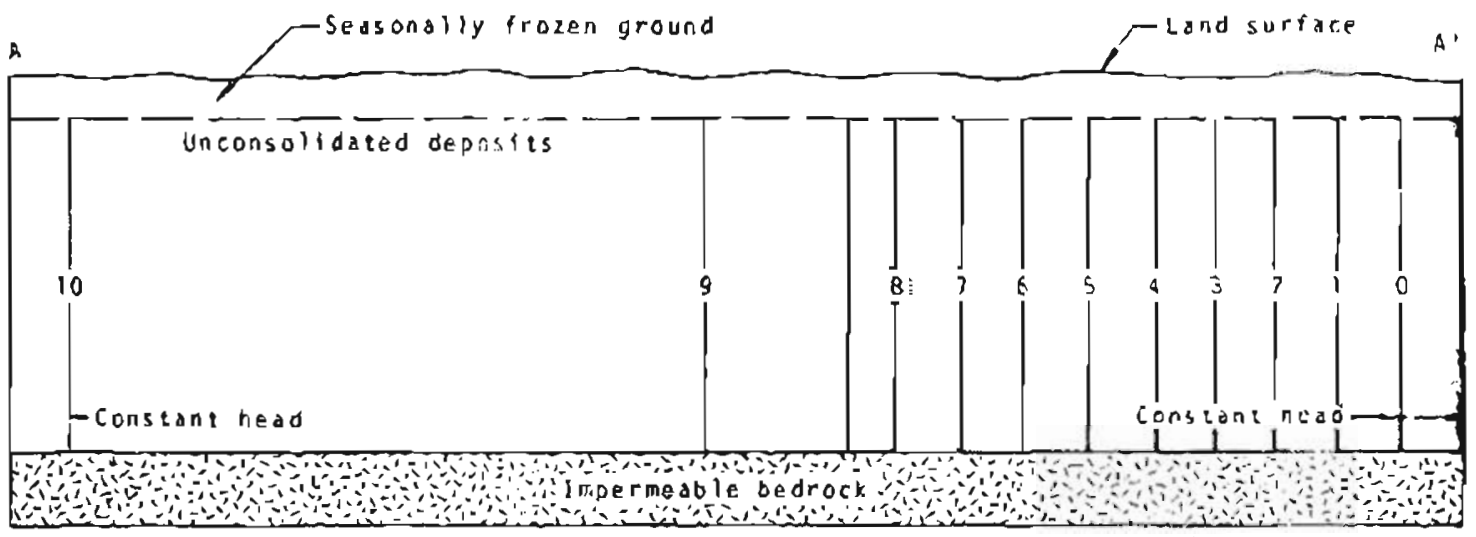

figure $3 C$.- Hed discribution in the winter without the pipeline.

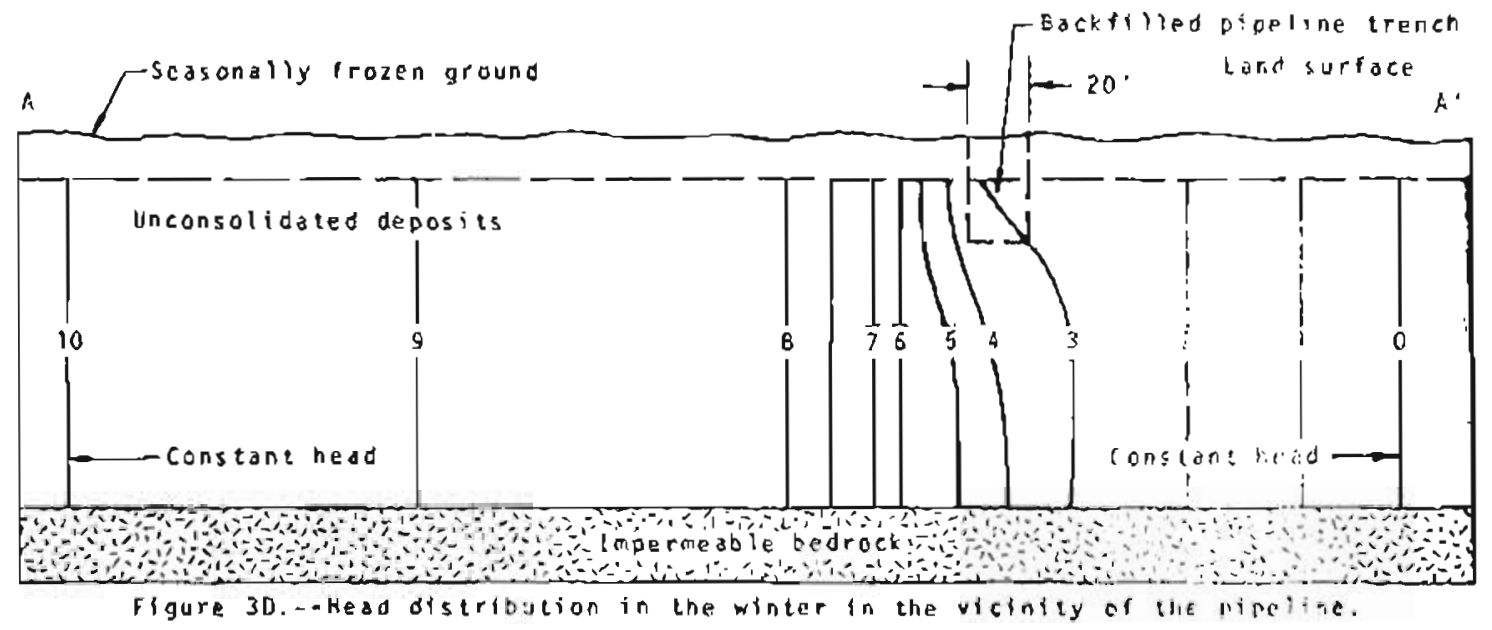




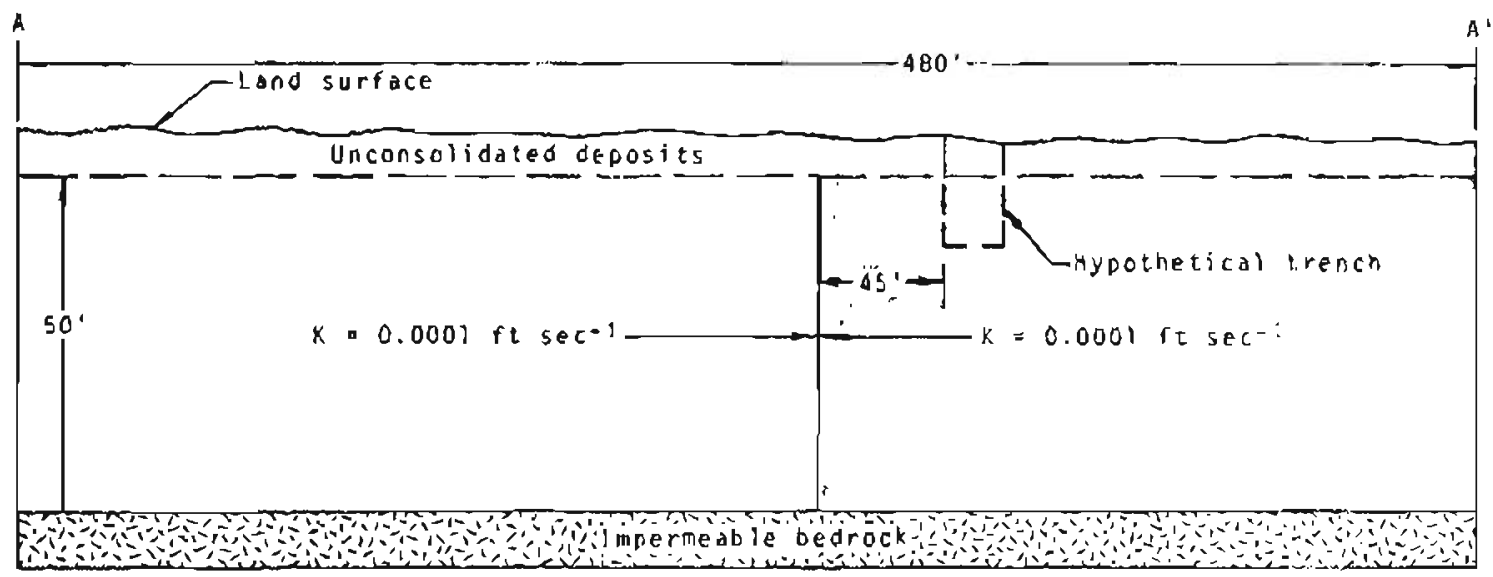

Figure $3 A$.--Geologic section A-A'.

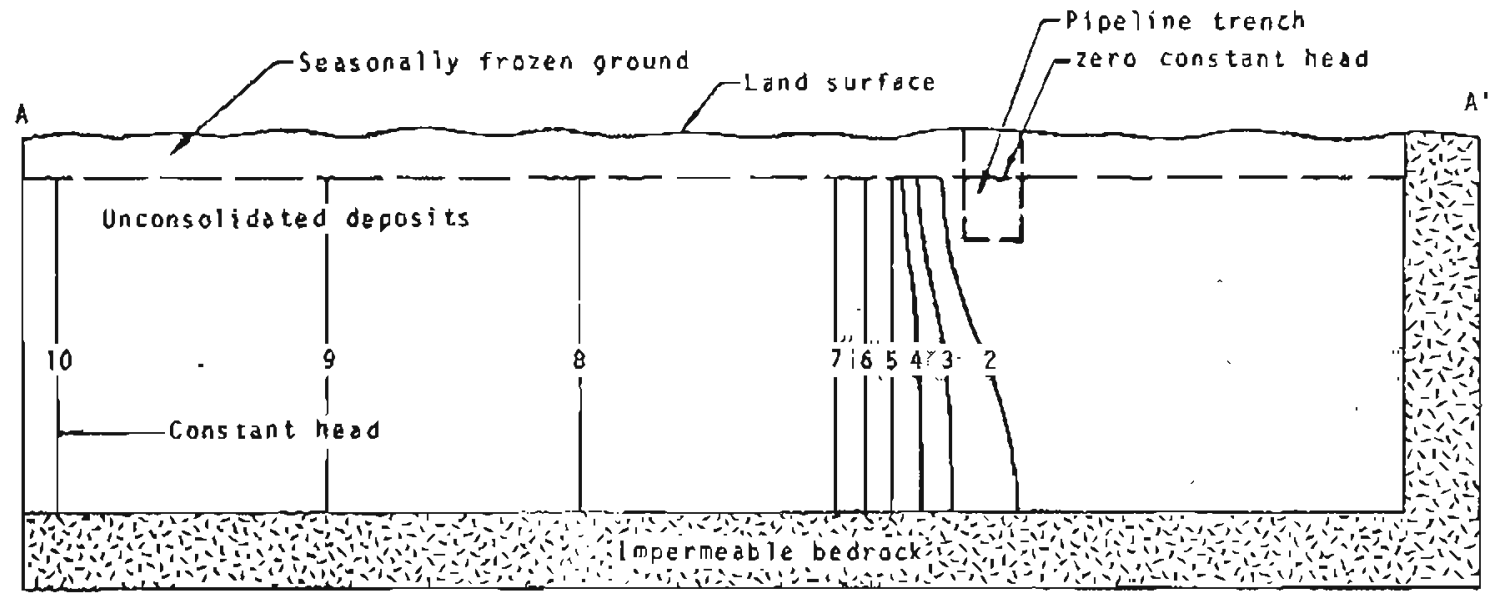

Figure 3E. - Head distribution in the winter with an impermeable barrier downstream.

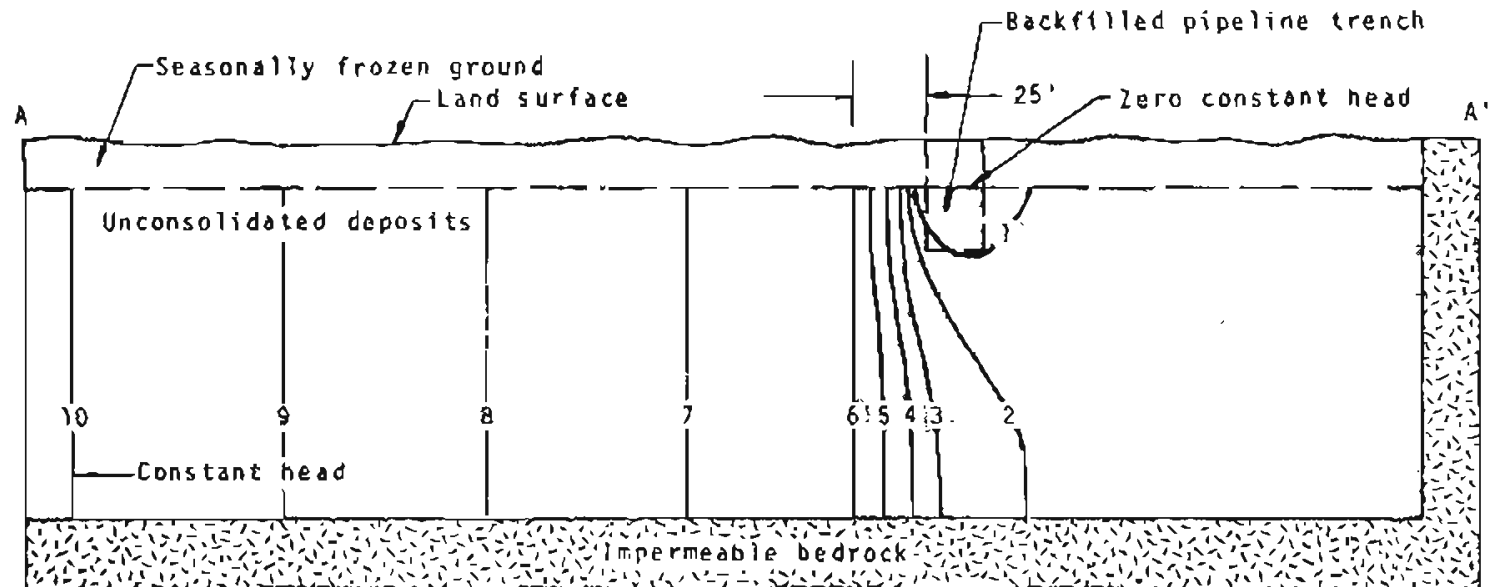

Figure 3F. - - Head distribution in the winter with the backfilled trench closer to the change in Delneability. 
Another situation causing potential problems is one in which the pipe is buried in a layer of low permeability that overlies a zone of higher permeability (fig. 4A). This situation is examined in figures $4 A-C$. Figure $4 B$ illustrates conditions with a contrast in permeability between layers of 10 times. The discharge is focused at the pipe trench; however, the head gradients approach 1 in 5. A change in the permeability contrast to a factor of 100 times causes a potential problem (fig. 4C): head gradients approach 1 in 1 , the critical value. This contrast, however, represents a fine sand or silt overlying a moderately permeable sand. As pointed out above, we have assumed the trench to be backfilled with material of the same permeability as that adjoinina it, in this case fine sand or site.

\section{MATHEMATICAL MODEL}

All computations for the model results (figs. 3 and 4) were made using finite-difference approximations for the equations of steady fiow. The model is described by pinder (1970). A rectangular grid with a horizontal grid spacing of 10 feet and a vertical grid spacing of 5 feet was used. The results based upon this grid are, therefore, somewhat approximate with head values obtained only at the grid intersections.

The finite difference approximation has a further difficulty at a sharp break in the permeability distribution. The geometric mean value of permeability between nodes is used in the computations. This means that a zone which is one grid width in thickness will have a value of permeability that is an average of the zones of differing permeability. 

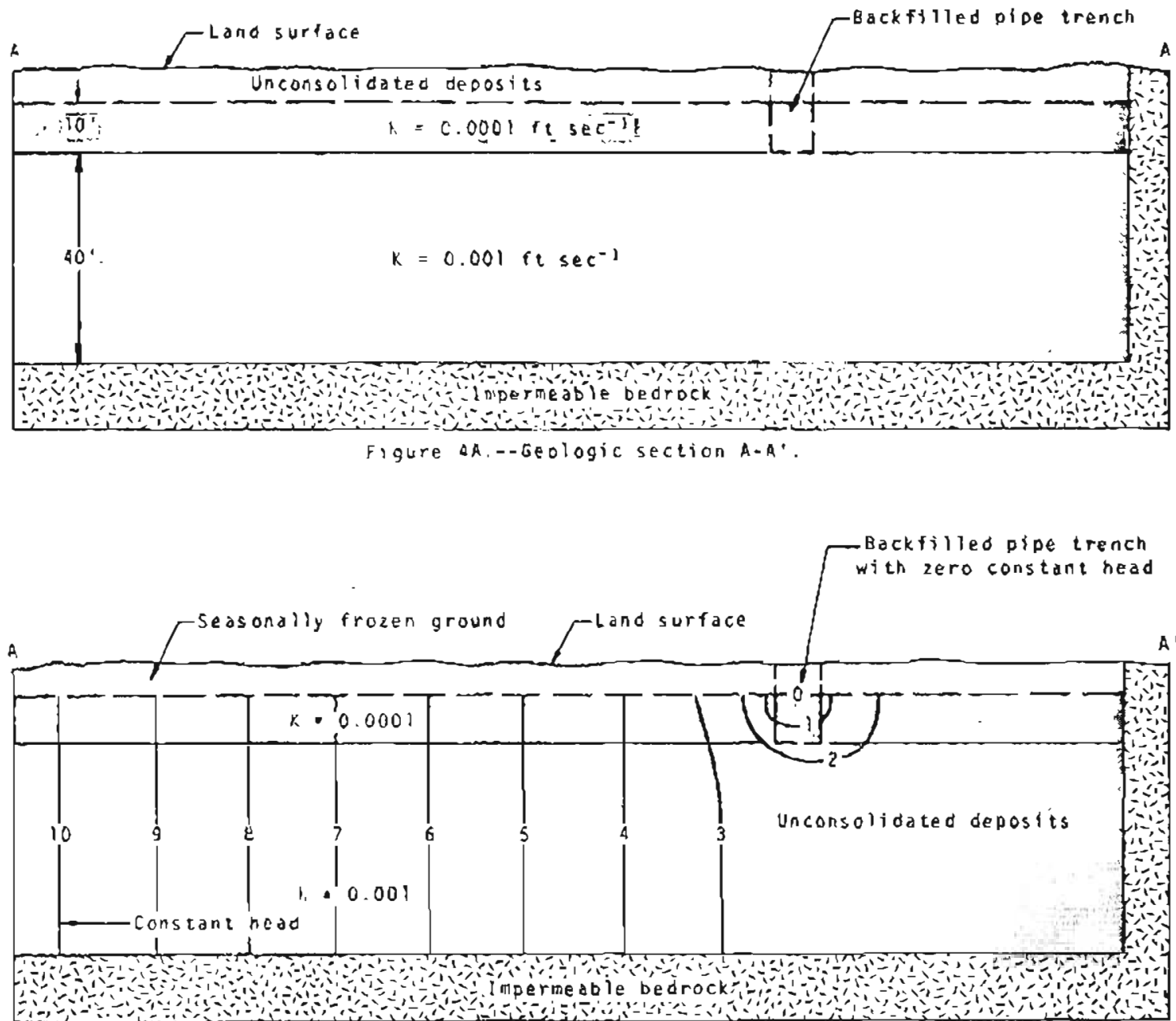

Figure AB... Winter head distribution with backfllied pipeline trench.

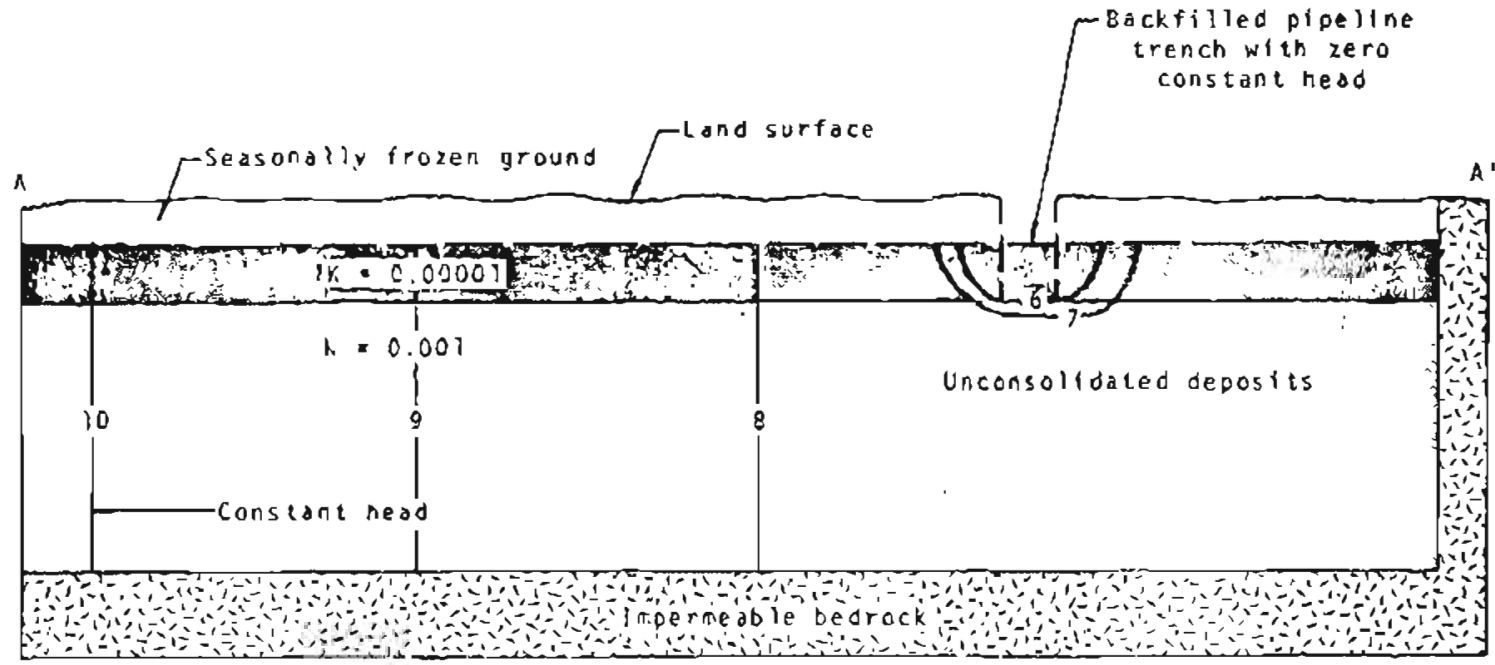

Figure 4C.--winter ncod clstribution with b iorger contrast in berneability between layers. 


\section{CRYOSTATIC PRESSURES DEVELOPED IN A SHALLOW TALIK}

Icing mounds, also called icing hillocks, are ephemeral pressure-relief forms that result from arching of aufeis. As generally envisioned, icing mounds occur as a result of freezing pressures in closed taliks at shallow depth beneath the seasonally frozen layer. High cryostatic pressures can develop in icing mounds; 52 atmospheres were measured in an icing mound in siberia by V.G. Petrov in 1930 (Chekotjllo and others, 1960).

Ponomarev and Tolstikhin (1964, p. 12) described the formation of icing mounds:

"The most distinctive feature of the water-bearing horizon being considered is not only the change of its thickness but also the transition from the free state into a pressure-head state during the year. During freezing the volume of water is in. creased and the remaining unfrozen water acquires a pressure head and wanders along the line of least resistance. The hydrostatic pressure of the horizon being considered increases towards the relief depressions. It is exactly here that the greatest stress in the ground is observed under the influence of this pressure causing the formation of heaving hummocks. The result of freezing in the depression is the formation of an unusually 'artesian' water-bearing horizon."

Chekotilio and others (1960, P. 52) quoted A.U. L'vov in a discussion of ground-icing hillocks as follows:

"With the formation of such hillocks in the form of ice laccoliths, we could observe a true eruption: from March to June these hillocks broke down, the water cut into the earth funnel-like openings and flowed from them at great force, carrying off rock and gravel." 
The authors ( $p .79)$ further stated:

"These pressures are the cause for the moving of the water and sometimes quicksand masses into the orotruding hillocks chiefly from the soi? layers located to the side of the hillocks."

Lewis (1962, p. 149 ) described an icing mound on the Sadlerochit River which he believed

"... showed evidence that uplift involved both cryostatic pressures accompanying growth of a ground-ice lens and later hydrostatic pressures accompanying a restriction of ground-water flow. The final uplift of the mound and concurrent cracking along the apex occurred explosively."

In conclusion, Lewis ( $p$. 150) stated:

"Because of widespread general similarity of hydrologic and geologic conditions in the valleys of most major rivers, icing mounds may be expected to occur frequently in association with aufeis fields on the Arctic slope of A laska."

Heat from a buried pipeline will prevent the formation of icing mounds near the pipeline, but it is remotely possible that an icing mound could form directly beneath, or quite near, an elevated pipeline. If measures were not taken to reduce internal mound pressures, it is conceivable that the mound could explode with effects to the pipeline similar to those described for the bridge on the onon River (Chekotillo and others, 1960, p. 92).

V.6. Petrov (Chekotillo and others, 1960, p. 92) described the explosion of an icing hillock on the onon River in March 1928:

"Along the axis of the highway, six icing hills had been formed; the second of them (working from the south) on the eve of the explosion was greatly cracked and shuddered, and at 5:00 A.M. on March 28 it exploded scattering enormous clumps of ice up to 19 meters long, 5 meters 
wide and 2 meters thick. Several blocks of ice (the largest ones) were carried by the stream of water bursting from the hillock more than 120 meters along the valley of the Onon River below the highway; the ice blocks in several seconds 'sheared off' a small bridge... the explosion was accompanied by a loud sound like a cannon shot; masses of ice were carried off by the water with a roar of a train. The catastrophic event on the onon River did not last long and in an hour or two everything was quiet, the water had flowed off, the ice had settled in the valley, and the only trace of the catastrophe was the clump of ice and the fragments of the bridge, flattened shrubs and the scratches on the bark of 1 arge trees from the ice."

\section{CONCLUSIONS}

\section{Quick Conditions}

The results of computations using the model suggest that although artesian conditions can occur in the winter beneath a seasonally frozen layer, high heads are not likely to develop. Test drilling along the proposed pipeline route generaliy confirms this conclusion.

Quick conditions do not appear likely to occur. The one exception may be if the pipe were to be buried in fine sand overlying a highly permeable layer of coarse sand or gravel, the situation depicted in figure $4 C$. Test drilling should identify this geologic setting. In this situation, care should be taken to backfill with permeable sand and grave I.

\section{Icings}

Al1 of the model results demonstrate that a heated trench of permeable material will form a good drain for ground water, especially in the winter. one can expect numerous "springs" associated with the backfilled trench, as almost every topographic low is a zone of potential 
wintertime discharge. These will no doubt increase the number and frequency of icings. In the major streams and on larger alluvial fans, these icings could be large and potentially troublesome.

\section{Icing Mounds}

Explosive icing mounds can probably be identified during their growth. Because of the explosive potential of these features. measures should be taken to relieve the internal pressures during their formation. 
Casgrande, Arthur, and Fadum, R.E., 1940, Notes on soil testing for engineering purposes: Harvard Univ. Grad. School of Engineering Publ. 258, $74 \mathrm{p}$.

Cederstrom, 0.J., 1963, Ground-water resources of the Fairbanks area Aiaska: U.S. Geol. Survey Water-Supply Paper 1590, $84 \mathrm{P}$.

Chekotillo, A.M., Tsvid, A.A., and Makarov, V.N., 1960, Naleds in the U.S.S.R. and their control. (Haledi na territorii SSSR i bor'ba $5 \mathrm{nimi.)}$ Blagoreshchensk: Amurskoe Knizhnoe Izdatel'stvo, $207 \mathrm{p}$. (Translated for USA CRREL 3965).

Lachenbruch, A.H., 1970, Some estimates of the thermal effects of a heated pipeline in permafrost: U.S. Geol. Survey Circ. 632, $23 \mathrm{p}$.

Lewis, C.R., 1962, Icing mounds on Sadlerochit River, Alaska: Arctic, v. 15, no. 2, p. 145-150.

Pinder, G.F., 1970, An iterative digital model for aquifer evaluation: U.S. Geol. Survey open-file report, $44 \mathrm{p}$. Ponomarev, V.M., and Tolstikhin, N.1., 1964, Ground water in permafrost areas $(p .328-364)$, chap. 10 in seneral Geocryology, pt. $T$ of Principles of Geocryology (Permafrost Studies), transiated by $C$. De Leuchtenberg: National Research Council of Canada Technical translation $1138,98 \mathrm{p}$.

Scott, R.F., 1963, Principles of soil mechanics: AddisonWesley Publishing Company, Inc., $550 \mathrm{p}$.

U.S. Department of the Interior, 1972, Appendix - Stipulations for proposed trans-Alaska pipeline, in Introduction and summary, $v$. 1 of Final Impact Statement, proposed trans-Alaska pipeline: National Technical Information Service (distributor), U.S. Dept. of Commerce, $322 \mathrm{p}$. 